'Zharassova D.N., ${ }^{1}$ Kenzhebayeva S.S., ${ }^{2}$ Minocha S., ${ }^{2}$ Wuddineh W., ${ }^{1}$ Omirbekova N.Zh., ${ }^{1}$ Bayandy G.A.

'Al-Farabi Kazakh National University, Almaty, Kazakhstan 2University of New-Hampshire, Durham, USA

Effect of drought on concentration of polyamines of new mutant lines of spring wheat

\author{
${ }^{1}$ Жарасова А.Н. \\ ${ }^{1}$ Кенжебаева С.С., \\ ${ }^{2}$ Миноча С., ${ }^{2}$ Вудиней В., \\ ${ }^{1}$ Омирбекова Н.Ж., \\ ${ }^{1}$ Баянды Г.А.
}

'Ә^-Фараби атындағы Қазақ ұлттық, университеті, Қазақстан, Алматы қ.

${ }^{2}$ Нью-Гэмпширский университет, АҚШ, Аарем қ.

Жаздық бидайдың жаңа мутантты ^иниямарының полиаминдер концентрациясына құрғақшымықтың әсері

\author{
'Жарасова А.Н. \\ ${ }^{1}$ Кенжебаева С.С., \\ ${ }^{2}$ Миноча С., ${ }^{2}$ Вудиней В., \\ 'Омирбекова Н.Ж., \\ ${ }^{1}$ Баянды Г.А.
}

'Казахский национа^ьный университет имени аль-Фараби, Казахстан, г. Амматы ${ }^{2}$ Нью-Гэмпширский университет, г. Аарем, США

ВАияние засухи на концентрацию полиаминов у новых мутантных миний яровой пшеницы
Wheat (Triticum aestivum L.) is grown in many countries around the world, its productivity is hampered due to a variety of abiotic stresses such as drought, salinity, and heat, particularly in arid and semiarid regions of the world. Of these, drought as complicated factor, is the major abiotic stress that is regarded as highly deleterious to growth and productivity of the wheat. Drought inhibits a variety of physiological processes in plants. Drought continues to be an important challenge to agricultural researchers and plant breeders. Drought is a major abiotic factor limiting the crops yield grown more than one third of the arable land around the world. Polyamines are endogenous plant growth promoters that affect a variety of physiological and metabolic functions, and they particularly involved in the flowering process. Studies conducted with other crop plants indicated that there is relationship between changes in polyamine content and drought tolerance. However, no information exists regarding to polyamine content of wheat under conditions of limited water supply. This study was aimed quantifying the effect of drought on different classes of polyamine such as putrescine, spermidine and spermine concentrationin the parent line Zhenis and $M_{-} \mathrm{mu}^{-}$ tant lines developed on its genetic basis using gamma radiation doses of 100 and 200 Gy resulting changes in their concentrations. The article presents screening parent variety of spring wheat Zhenis and $M_{-}$mutant lines developed on its genetic basis using gamma radiation doses of 100 and 200 Gy on polyamine content in plants grown under watered and drought condition. The wheat mutant germplasm, grown under irrigation had 4 samples, which are characterized by significantly increase in polyamines concentration. On the genetic basis of varieties Zhenis gamma radiation dose of $100 \mathrm{~Gy}$ on the basis of putrescine concentration have been identified two significant positive mutant linesunder drought conditions.

Key words: drought, polyamines, putrescine, spermidine, spermine, wheat, mutant lines.

Аүние жүзі бойынша бидайды (Triticum aestivum L.) көптеген елдерде өсіреді, құрғақшылық, тұздылық және жылу сияқты алуан түр^і абиотикалық стресстер, әсіресе әлемнің құрғақ және жартылый құрғақ аудандарында оның өнімділігін қиындата түседі. Құрғақшылық, ауылшаруашылық ғалымдар мен өсімдіктер селекционерлері үшін осы күнге дейін маңызды мәселелердің бірі болып саналады. Бұл зерттеу жұмыстары құрғақшылықтың полиаминдер (путресцин, спермидин, спермин) концентрацияларының әсерінің сандық бағалауына және олардың концентрацияларының өзгеруі нәтижелеріне бағытталады. Мақалада жаздық бидайдың бастапқы Жеңіс сорты мен 100 және 200 Gу дозаларымен гамма сәулеленуді қолданып оның генетикалық негізінде жасалған М мутантты линияларына скрининг берілген. Суарылған жағдайда өсірілген бидайдың мутантты гермоплазмаларында төрт үлгінің полиаминдерінің нақтылы анық мәнАі жоғары концентрациясы анықталған. Құрғақшылық жағдайында 100 Gу доза бойынша гамма сәулеленудің генетикалық негізіндегі Жеңіс сортының путресцин концентрациясы бойынша екі оң мутантты миниялар анықталды.

Түйін сөздер: құрғақшылық, полиаминдер, путресцин, спермиАин, спермин, бидай, мутантты миниялар.

В статье представлен скрининг родительского сорта яровой пшеницы Женис и М 7 мутантных линий, разработанных на его генетической основе с использованием гамма-излучения в дозах 100 и 200 Gу на концентрацию полиаминов в растениях, выращенных в условиях полива и засухи. В мутантной гермоплазме пшеницы, выращенной на поливе, идентифицированы 4 образца, характеризующиеся достоверно значимым повышенным содержанием полиаминов. На генетической основе сорта Женис гамма-излучения дозы 100 Gу на основе концентрации путресцина были выявлены две существенные положительные мутантные минии при засухе. Концентрация спермина увеличилась в Авух линиях Аоз 100 и 200 Gу при условии засухи. При засухе концентрация спермидина сократилась в Ава раза в 100 Gу и четыре раза в 200 Gy, в меньшей степени, по сравнению с сортом Женис.

Кмючевые слова: засуха, полиамины, путресцин, спермидин, спермин, пшеница, мутантные миний. 


\author{
${ }^{1 *}$ Zharassova D.N., ${ }^{1}$ Kenzhebayeva S.S., ${ }^{2}$ Minocha S., \\ ${ }^{2}$ Wuddineh W., ${ }^{1}$ Omirbekova N.Zh., ${ }^{1}$ Bayandy G.A. \\ ${ }^{1}$ Al-Farabi Kazakh National University, Almaty, Kazakhstan \\ ${ }^{2}$ University of New-Hampshire, Durham, USA \\ *E-mail: dynara_zharassova@mail.ru
}

\section{EFFECT OF DROUGHT ON CONCENTRATION OF POLYAMINES OF NEW MUTANT LINES OF SPRING WHEAT}

\section{Introduction}

Wheat production is threatened by abiotic stresses prevailing in wheat agricultural systems. The most important abiotic stresses affecting wheat production include drought, heat, cold and salt stresses. Global climate changes are predicted to further increase causing further crop vulnerability. Drought is one of the most common environmental stresses that affect growth and development of plants. Drought continues to be an important challenge to agricultural researchers and plant breeders [1].

Many strategies are adapted by plants as a resort to abiotic environmental stresses. These adaptive mechanisms include changes in physiological and biochemical processes. Among them the accumulation of polyamines in plant tissue has drawn much attention. The polyamines, mainly putrescine (Put, a diamine), spermidine ( $\mathrm{Spd}$, a triamine) and spermine ( $\mathrm{Spm}$, a tetramine), are polycationic compounds of low molecular weight which could accumulate under a variety of abiotic stress conditions [2].

Polyamines are low-molecular-weight organic polycations with two or more primary amino groups- $\mathrm{NH}_{2}$ and as shown they are present in bacteria, plants and animals. In plants, the diamine putrescine (PUT) and its derivatives, the triamine spermidine and the tetramine spermine are the most common polyamines and they have been reported to be implicated in a variety of plant metabolic and physiological functions [3]. Additionally, polyamines play a significant role in flower induction [4] along with flower initiation [5], pollination [6], fruit growth and ripening [7]. Research in other crops has indicated that changes in polyamines concentrations are a common plant response to a variety of abiotic stresses, including drought, salinity, high or low temperatures, and as well as biotic stresses [4].

Wheat (Triticum aestivum L.) is grown in many countries around the world, its productivity is hampered due to a variety of abiotic stresses such as drought, salinity, and heat, particularly in arid and semiarid regions of the world [8]. Of these, drought as complicated factor, is the major abiotic stress that is regarded as highly deleterious to growth and productivity of the wheat. Drought 
inhibits a variety of physiological processes in plants, and its most significant negative effect can be observed on photosynthesis [9-10].

Water stress is the major factor limiting crop production worldwide. Water stress is one of the main integral components of drought including high temperature and high intensity of solar radiation.It alters a series of physiological, biochemical, and molecular responses [11]. Enhancing plant drought tolerance is the major challenge faced by modern agriculture, where polyamines can play an important role [12]. Plant polyamines are associated with the response of plants to diverse environmental stresses [12-14]. An increase in the endogenous polyamine content was reported in water-stressed plants confirming stress-specific roles of polyamines. Moreover, those with a higher number of amino groups such as spermidine (Spd) and spermine (Spm)] were more effective in scavenging of reactive oxygen species, than putrescine [15-17]. In addition, the fluctuations of polyamine levels varied among plant genotypes. A significant increases in the free spermidine and spermine levels were observed in a drought-tolerant cultivar compared to increase of free putrescine levels in a droughtsensitive cultivar [18-19]. Furthermore, changes in the biosynthesis and catabolism of polyamines have occurred in plants under stress environments [13, 15, 19-21]. Decreased protein content and enhanced protein carbonyl formation have been also detected in stressed plants [22].

The objectives of our study were to determine the alterations caused by water-deficit on the polyamines content by their evaluation in wheat seedlings grown at watered and drought conditions in the parent line Zhenis and $\mathrm{M}_{7}$ lines of $100 \mathrm{~Gy}$ - and 200 Gy-dosed treatments developed on its genetic basis using these gamma radiation doses.

\section{Materials and methods}

The experiments were carried out in the year 2016 at the University of New-Hampshire, USA, Durham. The plant material used in the study were $10 \mathrm{M}_{7}$ mutant lines of spring wheat which were developed using by irradiation treatment (100 and 200 Gy)on genetic base of cultivar Zhenis (the parent line)[23]. For screening response to droughtthe parent line and mutant gemplasm were planted in pots in a in the tissue culture room. The seeds were sown in pots containing soil (SunGro, Professional Growing Mix). Ingredients of which were canadian Sphagnum peat moss, bark, vermiculite, perlite dolomite, lime and wetting agent. In water conditions plants were irrigated daily for 14 days. In drought conditions 7 days seedlings were grown. The germination was carried out under tissue culture room conditions. Samplesof leavesof 14-day old wheat seedlings grown under watered and drought conditionswere collected for polyamines analysis.

Dansyl chloride and all polyamine and acetylpolyamine standards were purchased from Sigma (St. Louis, MO, U.S.A.). Acetone, toluene (Photrex grade), HPLC-grade methanol and acetonitrile were supplied by J.T. Baker (Phillipsburg, NJ, U.S.A.).

\section{Extraction of polyamines and their dansylation}

The polyamines were extracted from leavesthree times by following freezing and thawing at room temperature. The polyamines extracts then were dansylated by following modifications of the procedure described by Smith and Davies [24]. Stock solutions of the various compounds were made in 5\% perchloric acid and diluted to obtain the necessary final concentrations. Aliquots (501) of each solution or the centrifuged tissue extract were placed in 1.0-ml Reactivials (Pierce, Rockford, IL, U.S.A.) containing $100 \mathrm{mkl}$ of a saturated sodium carbonate solution. A $100 \mathrm{mkl}$ volume of dansyl chloride solution in acetone $(10 \mathrm{mg} / \mathrm{ml})$ was added to each vial. The vials were capped tightly and incubated in the dark in a water bath at $60^{\circ} \mathrm{C}$ for $1 \mathrm{~h}$. A 50 mklvolume of proline $(100 \mathrm{mg} / \mathrm{ml})$ was added to the reaction mixture to remove excess dansyl chloride. After an additional $30 \mathrm{~min}$ incubation, acetone was evaporated from each vial by spinning under vacuum for 2 min in SpeedVac Evaporator (Savant, Farmingdale, NY, U.S.A.). A $400 \mathrm{mkl}$ volume of toluene was then added to the solution and each vial wasvortex-mixed for $30 \mathrm{~s}$. The vials were centrifuged at $500 \mathrm{~g}$ for $2 \mathrm{~min}$. After the aqueousand organic phases had separated, $200 \mathrm{mkl}$ of the toluene layer were transferred to anEppendorf tube. Toluene was completely evaporated in the SpeedVac and the residuedissolved in $1 \mathrm{ml}$ of methanol or acetonitrile.

\section{Analysis of polyaminesby high performance liquid chromatography (HPLC)}

The liquid chromatographic system (HPLC) consisted of a Perkin-Elmer series 400pump, a rheodyne injector valve fitted with a $6 \mathrm{mk} 1$ loop, a Perkin-Elmer Pecosphere-3x 3 CR Cls, 33 x 4.6 $\mathrm{mm}$ I.D. cartridge column ( $3 \mathrm{pm}$ particle size), and afluorescence detector (LS-1, Perkin-Elmer). The 
excitation and emission wavelengthswere set at 340 and $510 \mathrm{~nm}$, respectively. Peak areas were calculated using a LCI- 100integrator (Perkin-Elmer).

A helpful hint: When heptanes sulfonate solution was left in the bottle for severaldays, the growth of microorganisms (not identified) in the connecting tubes causedproblems with chromatography. The inclusion of $10 \%(\mathrm{v} / \mathrm{v})$ acetonitrile in the heptanesulfonatesolution eliminated this problem. Appropriate adjustments should bemade in the gradient profile to achieve the desired concentrations at each step [25].

\section{Results and discussion}

In our study 4 lines of 100-Gy dosed of spring wheat 5(4),6(5), 30(1) and 45(3) $\mathrm{M}_{7}$ mutant lines and the parent variety Zhenis were studied.

Putrescine concentrationin leaves ofparent variety Zhenis spring wheat seedlings grown under watered condition was $6.56 \pm 5.5 \mathrm{pmoles} / \mathrm{g}$ fresh weight (Figure 1, A). In leaves of 100-Gy dosed $\mathrm{M}_{7}$ mutant lines of seedlings grown under watered condition varied in the range of 6,93 to $20,29 \mathrm{pmoles} / \mathrm{g}$ fresh weight with a mean of $13.21 \pm 5,61 \mathrm{pmoles} / \mathrm{g}$ fresh weight for 4 lines (Figure 1, B).

At drought treatment, concentration of this polyamine in the parent variety Zhenis increased by 1.53 times.

In $\mathrm{M}_{7}$ mutant lines were found that putrescine concentrationsignificantly varied from 9.88 to $42,65 \mathrm{pmoles} / \mathrm{g}$ fresh weight with a mean of 22,81 $\pm 13,97 \mathrm{pmoles} / \mathrm{g}$ fresh weight for 4 lines (Figure
1, B). Genotypic response regarding to putrescine concentration in leaves under drought decreased in 5(4), 6(5) lines by about 0.90 , or significantly increased by $2.86-2.98$ times in 30(1) and 45(3) $M_{7}$ mutant lines

Thus, under drought, significant increase(about 3 times) in putrescine concentration were identified in leaves of two mutant lines 30(1) and 45(3) $\mathrm{M}_{7}$ developedbyon the genetic basis of $\mathrm{cv}$. the parent variety Zhenis and 100 Gy dose gamma radiation.

In our study we determined drought induced responses in spermidine concentration in leaves of the parent variety of spring wheat Zhenis and $\mathrm{M}_{7}$ mutant lines (Figure 2). Under watered treatment in the parent line Zhenisspermidine concentration was $15,46 \pm 8.5$ pmoles/g fresh weight. At the same conditions of growth spermidine concentration in 100 Gy-dose $M_{7}$ mutant lines of spring wheat ranged from 38.23 to 86,90 weight with a mean of60,01 \pm 20,38 pmoles/g fresh weight for 4 lines (Figure2, A).

Drought treatment induced great decrease in thespermidine concentration the parent variety of spring wheat Zhenis by 5 times with its value of 15.46 pmoles/g fresh weight (Figure 2, B).

In leaves of $\mathrm{M}_{7}$ mutant lines drought also caused a decrease in the spermidine concentration, however degree of this decrease was lowercompared with from 0.31 to 0.64 times with a mean of 0.47 for $M_{7}$ mutant lines. Genetic variations in the spermidine concentrations were in the range of 19,41 to $34,27 \mathrm{pmoles} / \mathrm{g}$ fresh weight with a mean of $26,57 \pm 6,9$ pmoles/g fresh weight for 4 these lines.
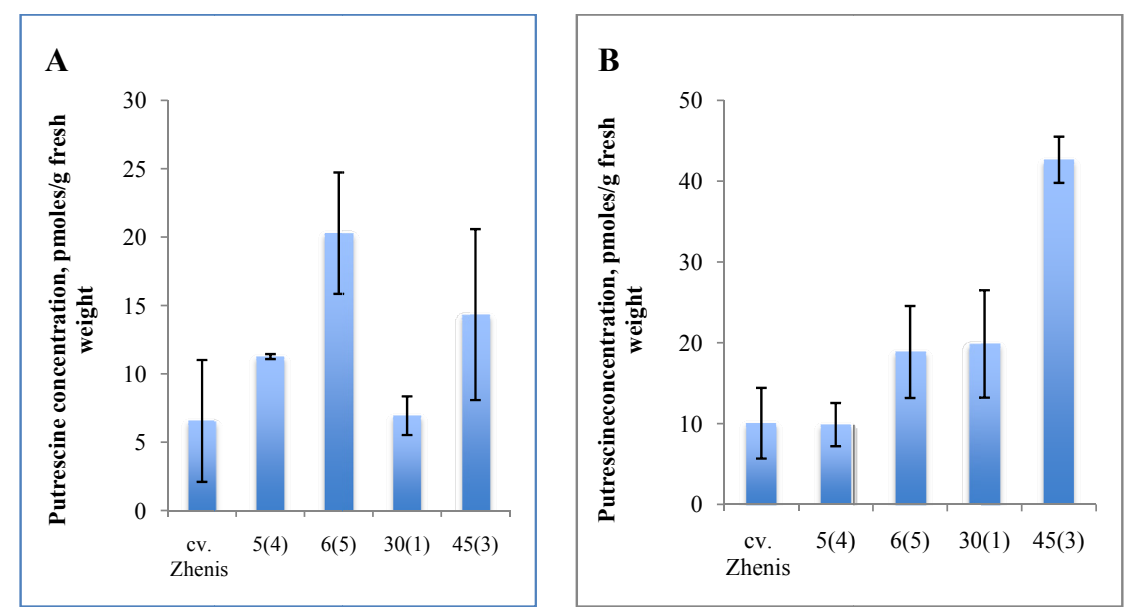

Figure 1 - Drought induced changes in putrescine concentrationsin cv. the parent variety Zhenis and $M_{7}$ mutant lines developedby its genetic basis and 100 Gy dose gamma radiation. (A) - watered and (B) drought conditions 

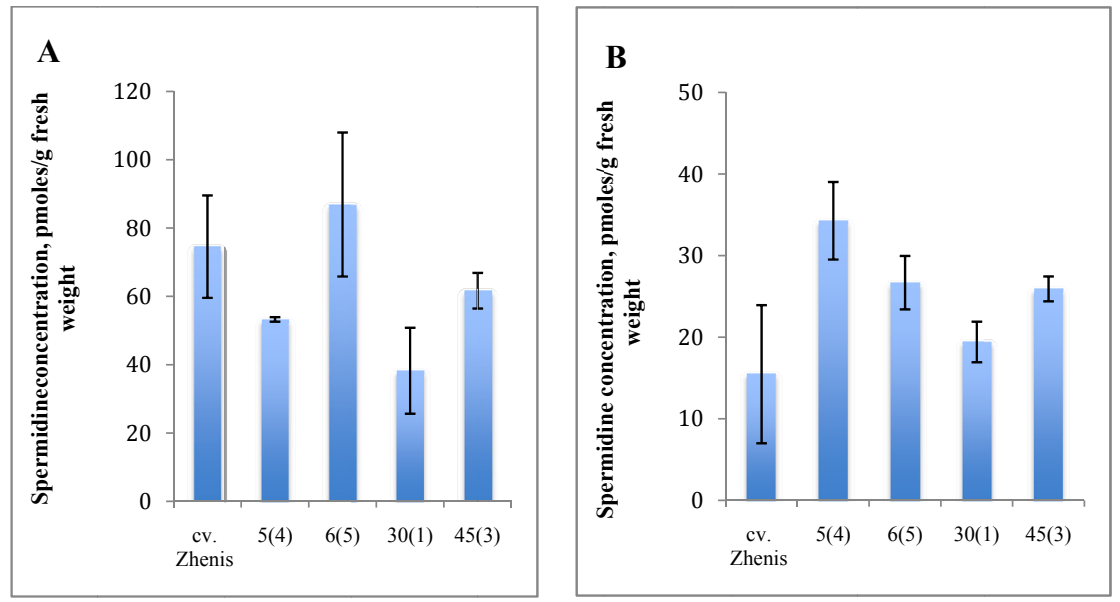

Figure 2 - Drought induced changes in the spermidine concentrationin cv. the parent variety Zhenis and $\mathrm{M}_{7}$ mutant lines developedby its genetic basis and $100 \mathrm{~Gy}$ dose gamma radiation. (A) - watered and (B) drought conditions

Figure 3 shows genetic variations in another class of polyamines tested such as spermine in our study in $\mathrm{cv}$. Zhenis and $\mathrm{M}_{7}$ mutant lines obtained on its genetic basis.
Spermine concentration in leaves of cv. cv. Zhenis at watered conditions of growth was determined as $79.61 \pm 11.2 \mathrm{pmoles} / \mathrm{g}$ fresh weight (Figure 3,A).
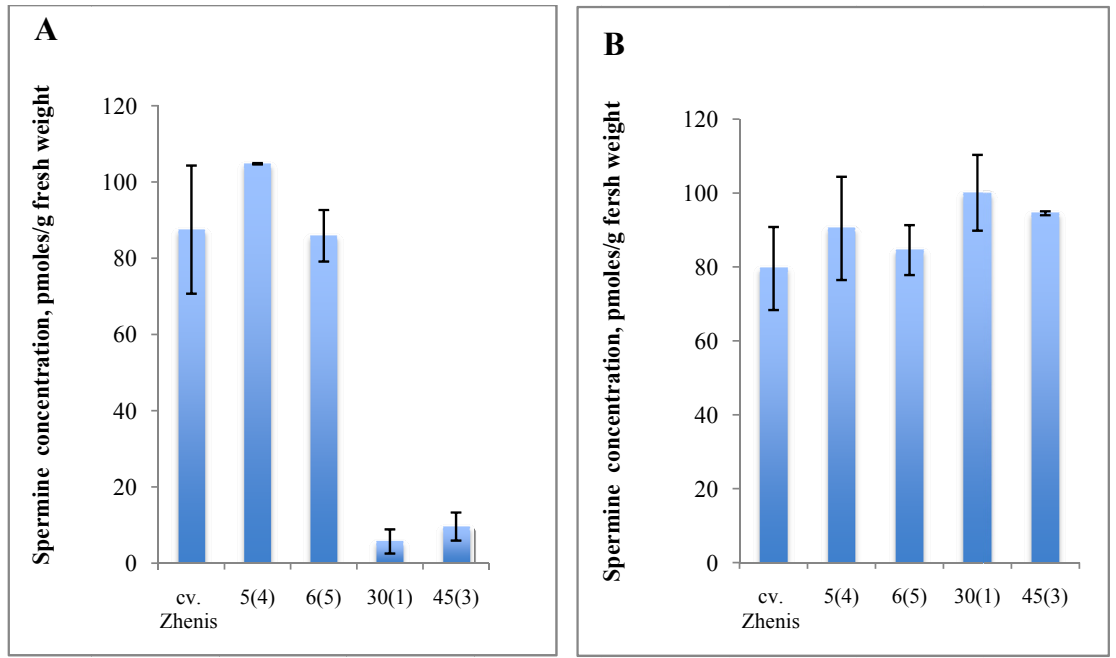

Figure 3 - Drought induced changes in spermine concentration in cv. the parent variety Zhenis and $M_{7}$ mutant lines developedby its genetic basis and 100 Gy dose gamma radiation. (A) - watered and (B) drought conditions

In $\mathrm{M}_{7}$ mutant lines spermine concentration varied in the range of 84,59 to 100,09 pmoles/g fresh weight with a mean of $92,42 \pm 6,55$ pmoles $/ g$ fresh weight for 4 lines (Figure 3, A). As indicate the results obtained, difference in spermine concentration at watered conditions between the parent line and mutant lines low. At drought, in cv. Zhenis spermine concentration almost was the same as it was found in waterd leaves with a mean of $79.61 \pm 11.2$ pmoles $/ g$ fresh weight (Figure 3, B).

Very interesting response in relation to the spermine concentrations were observed in $\mathrm{M}_{7}$ mutant lines grown under drought (Figure 3, B). Some lines 
such 5(4) and 6(5) showed the same response as the parent line, namely no drought -induced its changes. The lines 30(1)and 45(3) significantly increased spermine concentration in leaves by 17,56 and 9,84 times, with a mean of $30,71 \pm 20,3$ pmoles $/ \mathrm{g}$ fresh weight for 5 lines (Figure 3, B).
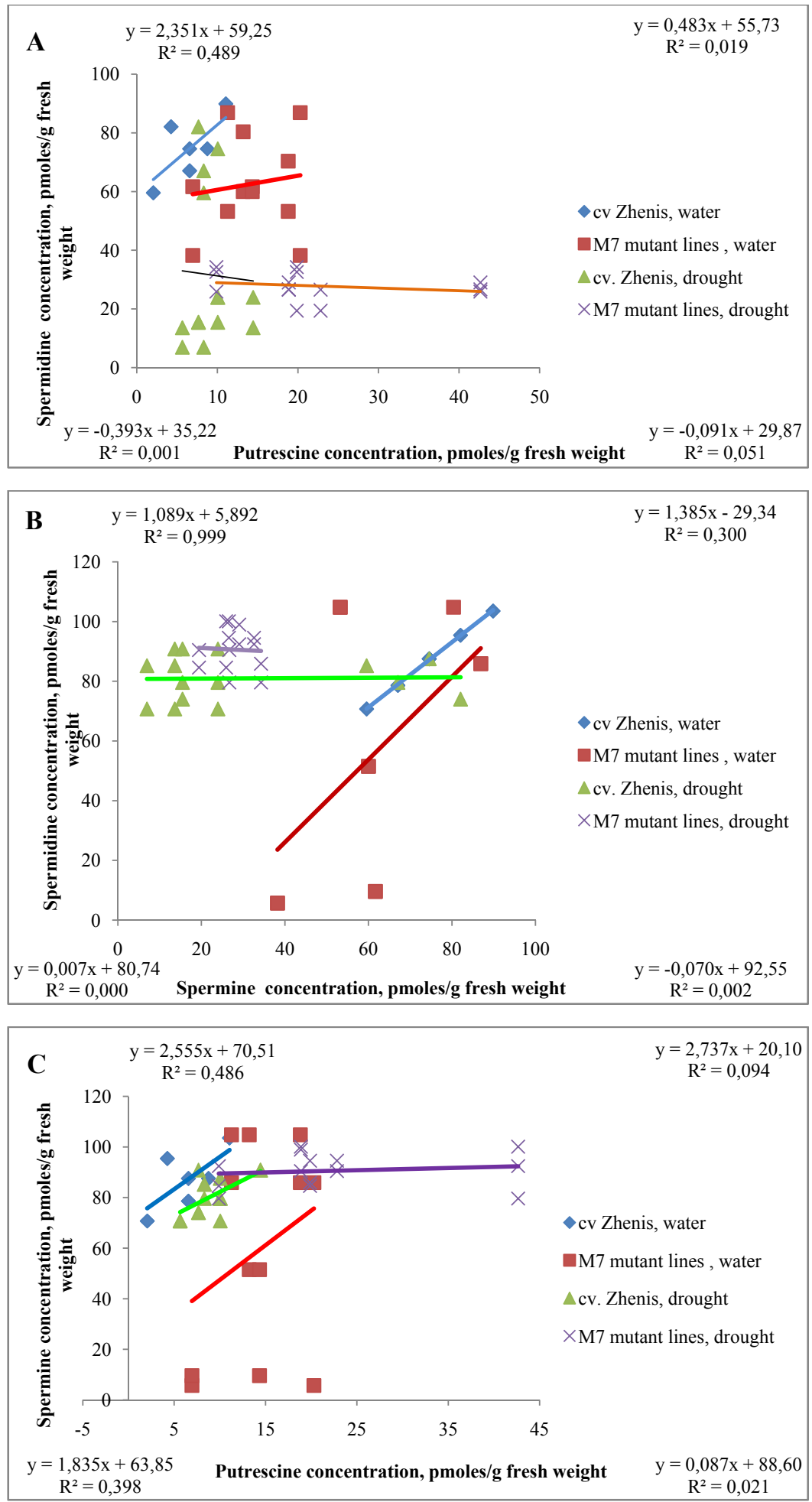

Figure 4 - Scatter plots of data for polyamines parameters, such as A - putrescinevsspermidine, $\mathrm{B}$ - putrescine vsspermine, $\mathrm{C}$ - spermine vs spermidine in the parent line Zhenis and $\mathrm{M}_{7}$ mutant lines developedby its genetic basis and $100 \mathrm{~Gy}$ dose gamma radiation at watered and drought conditions 
Thus, among three classes of polyamines such as putrescine, spermidine and spermine, determined in our research spermineshows the most pronounced response induced by drought in $\mathrm{M}_{7}$ mutant lines. Based on literature data we could assume its leading role related to drought resistance and the likelihood that the gamma radiation used to develop $\mathrm{M}_{7}$ mutant lines caused certain changes in the responsible for its synthesis genes.

To compare three classes of polyamines together one class to anotherScatter plots of data for polyamines parameters were used; the example plots are shown in Figure $4 \mathrm{~A}, \mathrm{~B}$ andC. These plots demonstrate the spread of values and a fitted correlation line to test if there was any evidence for a relationship between the parameters. These data showed that relations between each class of polyamines (putrescinevsspermidine, putrescine vsspermine, spermine vs spermidine) under watered conditions has a proportional relations (Figure 4). As it can be seen fromFigure 1 drought treatment had produced effect to change of this relation in the opposite one. When these relations of each class of polyamines were compared with the parent a much higher level of reduction was observed.

\section{Conclusion}

Polyamines (PAs) are small, positively charged, organic molecules that are ubiquitous in all living organisms. The three common PAs in plants are putrescine (Put), spermidine (Spd) and Spm, with some plants also having thermospermine (tSpm) in place of or in addition to Spm. It is not surprising that fluctuations in their cellular contents are often related to varied responses of plants to different forms of stress and to different phases of growth activity. As much as their cellular functions are diverse, and sometimes contradictory, so are their roles in plant stress. They have been deemed important in preparing the plant for stress tolerance and to directly aid in ameliorating the causes of stress, and at the same time, their own catabolic products are responsible for causing stress damage. Several aspects of the relationship between PAs and abiotic stress in plants and their seemingly contradictory roles in the process have been reviewed over the years [26-28].

\section{References}

1 NezhadahmadiA, Hossain ProdhanZ, FaruqG. (2013) Drought Tolerance in Wheat.Hindawi Publishing Corporation The Scientific World Journal. - Article ID 610721.- P.1.

2 KrishnamurthyR, BhagwatKA (1989) Polyamines as modulators of salt tolerance in rice cultivars. Plant Physiology, 91: 500-504.

3 KakkarRK, NagarPK, AhujaPS, RaiVK(2000) Polyamines and plant morphogenesis. Biol. Plant. 43:1-11.

4 Bouchereau A, AzizA, LahrerF, Martin-TanguyJ(1999) Polyamines and environmental challenges: recent developments. Plant Sci. 140:103-125.

5 Kaur-SawhneyR, TiburcioAF, GalstonAW(1988) Spermidine and flower-bud differentiation in thin layer explants of tobacco. Planta 173:282- 284.

6 FalascaG, FranceschettiM, BagniN, AltamuraMM, BiasiR (2010) Polyamine biosynthesis and control of the development of fruit pollen in kiwifruit. Plant Physiol. Biochem. 48:565-573.

7 KakkarRK,RaiVK(1993) Plant polyamines in flowering and fruit ripening. Phytochem. 33:1281-1288.

8 Emam Y (2011) Cereal Production. 4th ed. Shiraz, Iran: Shiraz University Press.

9 Chen W, Yao X, Cai K, Chen J (2011) Silicon alleviates drought stress of rice plants by improving plant water status, photosynthesis and mineral nutrient absorption. Biol Trace Elem Res 142: 67-76.

10 SarievaGE, KenzhebaevaSS, LichtenthalerHK(2010) Adaptation Potential of Photosynthesis in Wheat Cultivars with a Capability of Leaf Rolling under High Temperature Conditions, Russian Journal of Plant Physiology.-Vol. 57, No. 1, pp. 28-36.

11 Ribaut JM, Betran J, Monneveux P, Setter T (2012) Drought tolerance in maize. In: Bennetzen JL, Hake SC (eds) Handbook of maize: its biology. Springer, New York, pp. 311-344.

12 Gupta K, Dey A, Gupta B (2013) Plant polyamines in abiotic stress responses. Acta Physiol Plant 35:2015-2036.

13 Alcazar R, Altabella T, Marco F, Bortolotti C, Reymond M, Koncz C, Carrasco P, Tiburcio A (2010) Polyamines: molecules with regulatory functions in plant abiotic stress tolerance. Planta 231:1237-1249.

14 Talaat NB, Shawky BT (2012) 24-Epibrassinolide ameliorates the saline stress and improves the productivity of wheat (Triticum aestivum L.). Environ Exp Bot 82:80-88.

15 Groppa MD, Benavides MP (2008) Polyamines and abiotic stress: recent advances. Amino Acids 34:35-45.

16 Kubis' J (2008) Exogenous spermidine differently alters activities of some scavenging system enzymes, $\mathrm{H}_{2} \mathrm{O}_{2}$ and superoxide radical levels in water-stressed cucumber leaves. J Plant Physiol 165:397-406.

17 Zhou Q, Yu B (2010) Changes in content of free, conjugated and bound polyamines and osmotic adjustment in adaptation of vetiver grass to water deficit. Plant Physiol Biochem 48:417-425. 
18 Liu JH, Moriguchi T (2007) Changes in free polyamine titers and expression of polyamine biosynthetic genes during growth of peach in vitro callus. Plant Cell Rep 26:125-131

19 Zhang C, Huang Z (2013) Effects of endogenous abscisic acid, jasmonic acid, polyamines, and polyamine oxidase activity in tomato seedlings under drought stress. Sci Hortic 159:172-177.

20 Duan J, Li J, Guo S, Kang Y (2008) Exogenous spermidine affects polyamine metabolism in salinity-stressed Cucumis sativus roots and enhances short-term salinity tolerance. J Plant Physiol 165:1620-1635.

21 Talaat NB, Shawky BT (2013) Modulation of nutrient acquisition and polyamine pool in salt-stressed wheat (Triticum aestivum L.) plants inoculated with arbuscular mycorrhizal fungi. Acta Physiol Plant 35:2601-2610.

22 Bartoli CG, Gomez F, Martinez DE, Guiamet JJ (2004) Mitochondria are the main target for oxidative damage in leaves of wheat (Triticum aestivum L.). J Exp Bot 55:1663-1669.

23 Kenzhebayeva SS, Zharassova DN, Sarsu F, Dauir B, Omirbekova N(2016) Effects of drought on grain quality-and yieldassociated traits of advanced wheat mutant lines of spring wheat. 16th International multidisciplinary scientific geoconference \& EXPO SGEM 2016, Bulgary.-№1. - pp. 65-73.

24 Smith MA and Davies PJ (1985) Plant Physiol1985: 78-89.

25 MinochaSC, Minocha R,RobieCA(1990) High performance liquid chromatographic method for the determination of dansyl polyamines». Journal of Chromatography, Elsevier Science Publishers B.V., Amsterdam, 511 177-183.

26 Alet AI, Sanchez DH, Cuevas JC, Del Valle S, Altabella T, Tiburcio AF, et al. (2011) Putrescine accumulation in Arabidopsis thaliana transgenic lines enhances tolerance to dehydration and freezing stress. Plant Signal. Behav. 6, 278-286. doi: 10.4161/ psb.6.2.14702.

27 Hussain SS, Ali M, Ahmad M, and Siddique KHM (2011) Polyamines:natural and engineered abiotic and biotic stress tolerance in plants. Biotechnol.Adv. 29, 300-311. doi: 10.1016/j.biotechadv.2011.01.003.

28 Shi H, Chan Z (2014) Improvement of plant abiotic stress tolerance through modulation of the polyamine pathway. J. Integr. Plant Biol. 56, 114-121. doi: 10.1111/jipb.12128. 